\title{
The experience of immediacy: emotion and enlistment in fact-based theatre
}

Article

Accepted Version

Taylor, L. (2011) The experience of immediacy: emotion and enlistment in fact-based theatre. Studies in Theatre and Performance, 31 (2). pp. 223-237. ISSN 1468-2761 doi: https://doi.org/10.1386/stap.31.2.223_1 Available at https://centaur.reading.ac.uk/22120/

It is advisable to refer to the publisher's version if you intend to cite from the work. See Guidance on citing.

To link to this article DOI: http://dx.doi.org/10.1386/stap.31.2.223_1

Publisher: Intellect

All outputs in CentAUR are protected by Intellectual Property Rights law, including copyright law. Copyright and IPR is retained by the creators or other copyright holders. Terms and conditions for use of this material are defined in the End User Agreement.

\section{www.reading.ac.uk/centaur}

\section{CentAUR}

Central Archive at the University of Reading

Reading's research outputs online 
The experience of immediacy: Emotion and enlistment in fact-based theatre

\section{Lib Taylor, University of Reading}

\section{Keywords}

emotional enlistment

In-Yer-Face theatre

documentary theatre

state-of-the-nation drama

immediacy

political theatre

In the early years of the twenty-first century, critical discourses characterizing the theatre of the foregoing decade increasingly shared common ground in the distinctions and family resemblances that they identified. This was a moment when, suddenly and retrospectively, commentators on British theatre told the story of the recent past in similar and overlapping ways. Aleks Sierz's popular book prompted the identification of a 'new brutalist' theatre of the 1990s under the name In-Yer-Face Theatre (2001). This was a trend in theatre that, for Sierz, was characterized by the deliberate development of a confrontational form of 'direct' and 'immediate' theatre to cultivate an emotionally engaged audience. Chris Megson argues that the post-Thatcherite 1990s saw a renaissance in theatre writing based in 'directness' and 'immediacy’ (Megson 2006: 529-32). ${ }^{1}$ For Megson, this tendency can be traced in those two strands of British theatre that flourished in the final years of the twentieth and the early years of the twenty-first 
centuries: alongside the explosion of new work by young playwrights of the 'InYer-Face' movement, identified by Sierz, Megson places the revival in documentary and verbatim theatres about urgent, real events. Taking account of its critical, formal and political relationship with In-Yer-Face theatre, this article will develop Megson's proposition and argue that what fact-based theatre shares with much new writing of the 1990s is an attempt to channel emotion and feeling (sensation) as a way of engaging the audience. I will propose that strategies of immediacy and directness are integral to more recent versions of fact-based theatre, suggesting that they function critically to heighten emotional engagement in the drama as much as to promote intellectual understanding. This will lead me to consider what is at stake politically in the dynamics of what I will call emotional enlistment.

\section{A paradigm shift}

The 1980s saw a crisis in British theatre. A political shift to the right expressed by Thatcherism, the failure of the political left, withdrawal of money for the arts and a loss of confidence in theatre as a political arena collectively resulted in a nervous retreat from mainstream politics. ${ }^{2}$ Disillusionment with party politics saw new writing in the second part of the 1980s focus on single-issue politics, particularly the identity politics of feminism, race and gender, rather than the broad debates that defined the epic state-of-the-nation plays of the 1970 s. $^{3}$ Despite Howard Brenton and David Hare's mid-1980s analysis of contemporary Britain in Pravda (1985) followed by Hare's trilogy on institutions of state (1990, 1991 and 1993), the issues and dramatic forms that had preoccupied much new writing of the 1970s and early 1980s were not deemed appropriate for the more fragmented 1990s. Even narrowly defined identity politics were increasingly seen as too 
limiting a framework within which to examine the disintegration of old certainties and ideologies experienced in the early 1990s, and a generational chasm opened up in British theatre.

What moved into this conceptual vacuum were forms of theatre less interested in established models of political analysis and more interested in personal stories and an expression of the individual experience of 'how it is' or 'how it was'. ${ }^{4}$ This took two quite different yet linked forms, but each of these, I argue, was nevertheless derived from an existing theatre tradition. The first of these, In-Yer-Face theatre, was hailed as a radical departure from the state-of-thenation play. But though it brought fresh, new writers onto the scene whose nihilistic analysis of the contemporary demanded new definitions of political theatre, in its claim to diagnose and represent the competing discourses of the present it occupied similar territory to the state-of-the-nation play. Each of their claims to discursive authority was enabled by their location in subsidized theatre institutions that deliberately sought new writing. ${ }^{5}$ Furthermore, an existing ideology in British theatre of the primacy of authorship provided the conditions for writers to develop individual expressivity, marked by challenges to the norms of language and behaviour. Nevertheless the new writers could acquire increasing status through a revitalized expression of the current state of British society. Indeed, the more such work was open to charges of offensiveness, degradation and excess, the more established institutions supported it. Just as 1970s punk can be seen as a rejection of foregoing traditions of rock and pop music that was quickly co-opted by the structures of the commercial music industry, so In-YerFace theatre revitalized British theatre by challenging state-of-the-nation plays while also continuing in the tradition of taking the pulse of contemporary Britain. 
The second of these forms, documentary theatre, followed on the heels of In-Yer-Face theatre. It derived from a vigorous theatre tradition running alongside the scripted state-of-the-nation play, namely community theatre. Community theatres of the late 1960s and the 1970s gave voice to the experience of the working-class and other minority groups, using the techniques of devising drama out of testimony and the histories of 'ordinary' people that were developed by early twentieth-century Soviet agitprop theatre. ${ }^{6}$ The principle was to theorize experience, by producing performances that both described and analysed a collective position. Defined through political materialist frameworks, performances spoke to the local community but could also resonate beyond the specific example. This approach was exemplified by Peter Cheeseman's The Knotty (1970, first performed 1966), based on the history of the North Staffordshire Railway, encapsulating his belief that 'in the local is the universal'.? The 1960s-70s British theatre groups routinely engaged in specific political struggles, and their social embeddedness was formative for the expansion of community theatre, theatre-in-education and other forms of applied and political theatre in the 1970s and early $1980 \mathrm{~s}^{8}{ }^{8}$ The Thatcher years deprived these forms of theatre of their funding base, and their aims were ridiculed as outmoded and selfregarding. Fact-based theatre that developed in the late 1990s drew on similar approaches but, while sometimes focusing on the plight of individuals as a way of commenting on national concerns, eschewed any foregrounded theorizing of the material.

The problems for epic state-of-the-nation drama and agitprop/community theatre connect with a pervasive cultural climate that began to reject 'grand narratives' such as Marxism and feminist analysis as frameworks for creating 
political theatre. This was a period in the late 1980 s-early 90 s variously characterized as Postmodern Times, or the End of History, in which the ability to generate a coherent analysis of society, to locate an agent of change and a strategy to achieve it, were all called into question. The confidence of having a robust analytical and political metalanguage waned as the Left was perceived to have failed in its utopian or progressive aims and was regarded as out of date. Graham Saunders refers to Max Stafford-Clark's analysis of the 1990s as 'a self-conscious rejection of a model based on political analysis that distinguished earlier writers such as Howard Brenton and David Hare' (D’Monté and Saunders 2007: 3).

What remained was a vacuum in the discourses that could be adopted to create and structure a theatre with political aims. State-of-the-nation theatre depended for its critique on forms of Marxist historical materialism. The community theatres and Theatre in Education models of the 1970s and early 1980s had looked to Brechtian practices of distanciation in order to cultivate a critical spectator who could formulate possibilities of agency on the basis of understanding, but Brecht's ideas were discredited alongside Marxism in the wake of the collapse of the Berlin Wall in 1989. The impact of this left a new generation of playwrights with the imperative to show the 'new times', and in particular the changed moralities and bleakness of the present, but without a defined theory of progressive agency to bring to bear. Once confidence in progressive politics was challenged by the apparent failure of the organized Left to define political alternatives to capitalism and the collapse of the Soviet Union, new forms of engaging the audience were sought, forms that did not depend predominantly on rational materialist argument. Playwrights looked to emotion as a way of forcing an audience to feel the anger and frustration of late twentieth- 
century youth. Theatre that engaged the emotions had been mostly associated with Naturalism, or melodrama and musicals, each of whose analytical and political potential was questionable. But, in the 1990s, emotion was recuperated, not in the old Naturalistic modes but in the emergence of disquieting and desolate, yet sensational forms. These coalesced under the In-Yer-Face banner but, I would suggest, were deployed by documentary theatre too.

The 1990 s, then, saw a return to theatre that risked emotional engagement as a critical strategy. Emotion for In-Yer-Face theatre meant immersion in a fictional world that could be repellent, disturbing and desperate. The aim, as the name for this drama indicates, was to bring a fictional world up close. A group of new playwrights spoke to a young, disaffected audience who rejected the binary left/right ideologies of pre-1989 and who were struggling to find a voice that would represent their disappointments, alienation from society, impotence and dissatisfaction. Their frustrations could not be located in existing political discourse, and the traditional political parties failed to represent them. The writers now grouped as 'new brutalists' (such as Sarah Kane (2001), Mark Ravenhill (2001) and Anthony Neilson (1998)) shared an apocalyptic and sometimes nihilist attitude to the possibilities for change, and created work that aimed to confront audiences with the disconnection, despair and degradation of contemporary society. They used the resources of performance to create a direct, visceral audience engagement: 'Most In-Yer-Face plays are not interested in showing events in a detached way and allowing audiences to speculate about them; instead, they are experiential - they want audiences to feel the extreme emotions that are being shown on stage' (http://www.inyerface-theatre.com/what.html). The 
motivation to show 'how it is' was not accompanied, however, by a workedthrough notion of how things could be different.

While we associate post-1990 British theatre with emotionally affecting and immersive, confrontational theatre, it was accompanied by fact-based theatre that addressed the audience's desire for affect and experience in quite another way but one that was also emotional. In-Yer-Face theatre sought its politics through shock and disgust. Fact-based theatre addressed events and issues that belonged squarely in the realm of political discourse, but treated these things by engaging the audience, at least in part, emotionally in the detail of real stories. The mode of the audience engagement is a key factor here. Megson stresses the synchronicity of the emergence of new theatre writing based in 'directness' and 'immediacy', and the revival of documentary theatre - of what Peter Weiss called 'a theatre of actuality' (Weiss 1971). Megson states 'The simultaneity here is important since it suggests that, in the distinct field of new playwriting and verbatim drama, what might be called a vigorous "poetics of immediacy" emerged in British Theatre' (Megson 2006: 531). The 'poetics of immediacy' incorporates an urgency and connectedness that elicit an emotional response. However, this insight leads to the questions of whether the emotional response is itself political and how it might be connected to a political analysis.

\section{Documentary theatre as a response to crisis}

Fact-based theatre is not a homogenous theatrical form; rather it is an attitude to the source material used for dramatic construction. In recent times this has taken three predominant forms, though these forms are tendencies, not always distinct from one another. First, verbatim theatre, like Black Watch (2007) and 
Guantanamo (2004), is based in the representation of the actual words of real people collected through, for example, interviews or letters. Second, tribunal theatre, like The Colour of Justice (1999) and Justifying War (2003), is based on court and public enquiry transcripts and also uses actual words, but they are collected from formal documents and court records. Third, documentary plays, such as David Hare's The Power of Yes (2009) and The Permanent Way (2003) and Robin Soans's Talking to Terrorists (2005), juxtapose key historical turning points or situations. Documentary plays make use of interview material and documents that are transposed and edited into theatrical texts, and draw on techniques developed by companies such as the Living Newspaper arm of the Federal Theatre Project and Joint Stock Theatre Company. ${ }^{9}$ Contemporary documentary theatre engages with the real but, as distinct from its pre-1989 antecedents, eschews an analytical and theoretical metalanguage. That is not to say that documentary theatre lacks a point of view, since the selection of testimonial discourses included in the drama will have been designed to be positioned close to or at a distance from the audience's expected knowledge. But contemporary documentary theatre focuses, whether by adopting postmodern, self-referential forms or by taking an approach that draws on accepted conventions of authenticity, on the presentation of 'what really happened' rather than framing the performance by a pre-existing point of view. The 'raw' material is offered in order to engage audience sensibilities and for them to 'make up their own minds'.

Moreover, if the experience of In-Yer-Face theatre is one of confrontation or shock, documentary theatre matches this by replacing sensation with a kind of realism that we can call revealing or unveiling. Max Stafford-Clark commented: 
'I mean really what a verbatim play does is flash your research nakedly. It's like cooking a meal but the meat is left raw, like a steak tartar [sic]' (Hammond and Steward 2008: 51). But flashing the research does not have the visceral, shock effect that is found in the climaxes of some scripted 1990s and 2000s new brutalist drama. Its relationship with the audience is different because in documentary theatre it is the status of the material as 'true' and 'authentic' that makes it shocking. It is not that the meat in steak tartare is unprocessed - it is as produced as any other steak dish, but its rawness is its central characteristic. Factbased theatre flaunts the distinctiveness of its raw but processed research to engage the audience emotionally. It develops a specific mode of audience address that draws on, but has an ambivalent relationship with, identification, sympathy and didacticism. Its purpose is to bring the audience 'on-side' rather than prescribing an interpretation. Fact-based and verbatim forms of theatre deploy strategies of what could be termed 'enlistment' to align their audiences emotionally with particular political perspectives on recent events and controversies. However, it must be acknowledged that such political perspectives might enlist the audience in either a critically progressive or conservative project.

The unveiling or revealing of a group of connected events, actions and processes in documentary theatre focuses on injustices, bad choices and ineffectual procedures. For instance, The Colour of Justice (1999) and Gladiator Games (2005) both concern the failure of the British justice system. ${ }^{10}$ There are victims who are circumscribed by political decisions, bureaucratic routines and covert or half-perceived ideologies. Justifying War (2005) and Bloody Sunday (2005), for example, both consider injustices perpetrated by the British Establishment. ${ }^{11}$ The (re)presentation of a real event, framed and configured to 
expose its tragic or disastrous consequences, engages the audience as if present at a current happening. The spectator is not positioned at a Brechtian critical distance, to take on a political point of view, or simply to identify with an individual character. $\mathrm{S} /$ he is somatically moved by her/his moment-by-moment experience of the event in, and as, the present, and thereby feels connected to the incidents and their consequences.

Drawing on the work of film theorist Vivien Sobchack, Janelle Reinelt makes a valuable link between realism and experience in her claim that, 'The value of the document is predicated on a realist epistemology, but the experience of documentary is dependent on phenomenological engagement' (Reinelt 2009: 7). She proposes that in watching fact-based theatre, 'Spectators come to the theatrical event believing that certain aspects of the performance are directly linked to the reality they are trying to experience or understand' (Reinelt 2009: 9). Following the break down of East/West binary political ideologies and as people were looking for new ways of engaging with texts, Sobchack, writing about film spectatorship, challenges Marxist and psychoanalytic materialism as the dominant theories of film analysis, claiming they have 'obscured the dynamic, synoptic and lived-body situation of both the spectator and the film' (Sobchack 1992: xv). She highlights the felt sense of 'the embodied experience of labour, alienation, engagement, and transformation'. Transposed to theatre, this argument locates realism not as verisimilitude but as underwritten by the veracity of an experience, a recognition of a shared understanding that is at least partly found in an emotional response to a situation, which 'feels' connected to the experience of the spectator.

\section{Enlistment as a theatre strategy}


The affect of emotional engagement plainly functions differently in documentary theatre than the violent, visceral shock of In-Yer-Face brutalism. The intention of the emotional dimension in documentary theatre is not to alienate the spectator nor to develop identification with character through naturalistic absorption in the plot and mise-en-scène, but to confront the audience with a raw harshness that they would nevertheless feel physically and respond to somatically. Fact-based theatre does not aim to provoke or alarm its audience aggressively; its intent is to use emotion to embrace its audience, to bring them on side to recruit them. Rather than educe bodily revulsion, fact-based theatre develops strategies of enlistment, to align audiences with particular political perspectives on recent events and controversies - and to align them both rationally and emotionally. The notion of enlistment captures rational and observational modes of engagement but incorporates how this process is marshalled by the emotional. The audience gets on-side, not of the individual characters but of the case made by the drama.

As a transitive verb, 'to enlist' means to secure the support or cooperation of someone else; it implies gaining sympathy and winning over. There is persuasion but nowadays nothing as strong as coercion or compulsion. Nevertheless, once enlisted, supporters participate actively in whatever cause or enterprise they have signed up to. As an intransitive verb, 'to enlist' means to sign up for the armed forces and to be ready to die for one's country. To enlist in this sense means to represent in the most extreme and visceral way one side of a conflict or one position in a dispute, even if the full implications of the act of enlistment are not initially foregrounded. In the United States, the wording of the current oath of enlistment is:

I, ___ do solemnly swear (or affirm) that I will support and defend the 
Constitution of the United States against all enemies, foreign and domestic; that I will bear true faith and allegiance to the same; and that I will obey the orders of the President of the United States and the orders of the officers appointed over me, according to regulations and the Uniform Code of Military Justice. So help me God.

(US Code 1960)

This affirms that the soldier is required to be absolutely 'on-side' in a way that takes two forms. First, the enlisted man or woman accepts a position in a hierarchy whereby he or she cedes authority to someone else. Another person's vision of the world and future actions consequent on that vision are given greater validity than one's own contingent point of view. Second, the enlisted person promises to 'bear true faith' to an idea, internalizing a set of beliefs that will become indistinguishable from their own. An enlisted person joins a group who will act together and who will share beliefs, suggestive of the public and collective nature of the theatre audience, and also of the ideological weight that emotional engagement with drama can carry. I have coined the term enlistment to suggest the connection of fact-based drama with public affairs and the concept of theatre as a public sphere in which joining-in with debate may lead to joining-up with a shared point of view.

Enlistment might exploit an existing sympathy, or aim to shift the spectator from a position of passive sympathy to active participation. It may also denote reasoned and persuasive argument that addresses the spectator not as neutral and uninformed but as open to argument and unconsidered possibilities. Of course, enlistment is a military term, and the overwhelming focus of post 9/11 
British fact-based drama has been on the conflicts with Iraq and Afghanistan and their fall-out. Issues arising from the ethics of going to war and the conduct of politicians around these conflicts have underpinned work by the Tricycle, Stafford-Clark, Hare, Soans, Burke, and Brittain and Slovo, amongst others. This work enlists the audience as resistant, and specifically in opposition to government (regardless of that government's political complexion) through emotional attachment to ideas of ethical or moral responsibility. The audience is enlisted to take on a combative role where the emotional energy that in In-YerFace theatre is harnessed in rage, disgust or panic becomes the resource for collective indignation or zeal. The emotional dimension that is a component of enlistment gives the performances an immediacy and directness that link them with the apparently very different phenomenon of In-Yer-Face theatre. Both InYer-Face theatre and documentary theatre respond to a perception of a decisive shift in both British society and British theatre.

\section{Black Watch and Guantanamo}

It is difficult to evaluate the political effectiveness of enlistment in documentary theatre of the post-political 'new times' when the ideological certainties of the preceding decades had been eroded. The politics of enlistment in documentary theatre might be resistant or complicit, or even contain elements of both. I will discuss forms of emotional engagement in two fact-based dramas, Black Watch (2007, first performed 2006) and Guantanamo (2004). Black Watch was developed by the National Theatre of Scotland with playwright Gregory Burke, and directed by John Tiffany. The play was based on interviews with members of the Black Watch Regiment following its tour of duty in Iraq. Guantanamo: Honour Bound to Defend Freedom by Victoria Brittain and Gillian Slovo was 
directed by Nicolas Kent and Sacha Wares at the Tricycle Theatre, London. It wove together the personal stories of detainees in the United States' notorious illegal prison camp at Guantanamo Bay in Cuba, their lawyers and their families. Both plays address the global 'War on Terror' by focusing on a group of characters who are presented as the victims or dupes of this large-scale political strategy. In Black Watch, the protagonists are almost all Scottish soldiers who fight overseas in the British army against so-called terrorist insurgents. The play presents action deriving from the descriptions of, and comments on, serving in Iraq from the servicemen, and includes highly physical, stylized stage recreations of combat as well as formalized movement and realistic dialogue. In Guantanamo, the protagonists are people from the United Kingdom who are suspected of being Islamic terrorists, and who are detained and then held in the prison camp. The play presents their stories by means of letters they have written, and letters and documents produced about their situation by lawyers, politicians and family members. The play is similar in form to the tribunal plays that have been developed at the Tricycle in being based on relatively static staging and the reading of source documents. What marks Guantanamo as distinct from the tribunal plays is the critical absence of the court, trial and judge, indices of the processes of justice that are denied to the detainees.

Black Watch declares at its outset that it is fact-based drama, though it takes an unusually theatrical form for documentary theatre. Indeed it is its theatricality that contributes strongly to its process of audience enlistment. It is based on verbatim interviews with soldiers of the regiment, and the actors themselves underwent military training in marching, weapons drill and correct uniform protocols, to give the performances conviction. Black Watch is not 
peopled by either star performers or historical figures. The characters depicted are almost all working-class infantrymen, but the audience has no access to these real people and so no index for matching individual performer to a precise person. The play is about a group, and the community's identity is more significant than that of the individuals who comprise it. It is realist in a strict sense; in its acknowledgement of the theatre space at the beginning of the play, and its placing of The Writer as a character on stage, gathering testimony from the soldier characters. The play is not illusionistic; it uses TV news footage and BBC radio to anchor its action to real events, as well as a kind of gritty realism of language and gesture that shifts at key points into stylized performances based in movement, choric chants and singing, and theatrical reconstructions of regimental history. Despite its topic, language, dance and music transform the performance at moments into a celebration of Scotland and the soldiers' shared allegiance to the regiment and to each other.

The focus on working-class infantrymen leads to a complex reading of the soldiers. They are inadequately educated but heroically loyal to each other. Their vivid understanding and experience of the war they are fighting is not matched by a sophisticated political analysis of their own role in it, yet they are only too aware of the exploitation to which they are submitted, in the name of a country to which they are not emotionally bound. Their reverence for regimental tradition runs alongside sexist, racist and homophobic aggression, a propensity to brutal violence and childish bravado. Yet, the play enlists the audience on the side of these flawed and exploited characters by using theatricality based on music, lighting effects, ritual movement and coups de théâtre. The play ends with a 
military Tattoo, where stirring bagpipe music accompanies the soldiers moving together as a body:

The bagpipes and drums start playing 'The Black Bear'. [...] The parade formation begins to disintegrate, but each time one falls they are helped back onto their feet by others. As the music and movement climax, a thunderous drumbeat stops both, and the exhausted, breathless soldiers are left in silhouette.

(Burke 2007: 73)

The effect at the end of the play is to enlist enormous respect and sympathy for these men as people, in contrast to the political strategy they enforce. This factbased drama offers an understanding of who fights, how and what war feels like for the soldiers. It achieves this not by the sober and analytical recreation of the tribunal plays, but rather by spectacle, theatricality and pathos. But it enlists the audience both to support the characters and to credit the work of the actors, since the play demands as much physical and emotional energy as any In-Yer-Face performance, and wrings as much anguish and feeling from its audience. It is both a commentary on a real event and an affective theatrical event, and it invites awareness of effort, commitment and truth in each of those respects.

Guantanamo works in a quite different way though it deals with the same narrative: the narrative of the War on Terror, this time explored through the experience of civilians accused of being involved in the planning of terror attacks. Unlike Black Watch, it adheres to the tendencies in British documentary theatre that Stuart Young describes: 
eschew[ing] all touches of theatricality, emphasizing above all the faithful representation of the words, vocal inflexions, and physical gestures of their interviewee-characters.

(Young 2009: 73)

It adopts a verbatim form, with exact words edited to construct the point of view of the play. The performance style is spare, using direct audience address and very little theatricalization beyond the iconic orange suits of the prisoners, some simple indications of the Guantanamo cells and the calls to prayer that mark out the play as taking place across the course of a single day.

The play begins with a speech by Lord Justice Steyn, which contextualizes the setting up of a prison at Guantanamo Bay as a place for holding prisoners 'beyond the rule of law, beyond the protection of any courts, and at the mercy of the victors' (Brittain and Slovo 2004: 7). It ends by returning to Lord Justice Steyn, who condemns the detention at Guantanamo, questioning its legality and the ethics of holding prisoners without trial. He quotes John Donne saying 'any man's death diminishes me, because I am involved in Mankind; And therefore send not to know for whom the bell tolls; it tolls for thee' (Donne 1987: 86). This stirring passage is counterposed with factual voice-over, announcing that UK citizens are 'among more than 650 prisoners held in Guantanamo. [... They are being held indefinitely' (Brittain and Slovo 2004: 59). The Steyn speeches contextualize the play and frame the perspective of the performance as one that is oppositional to the US State.

The main body of the play comprises statements from letters, interviews, press conferences and court transcripts that not only are factual but also express 
disruptions to working and family lives. The touching letters and appeals for compassion and understanding validate the apparent innocence of the detainees by establishing shared 'universal' values with the audience. So quite different registers of discourse operate together towards the same end. Juxtaposition works visually too, since the performers playing the prisoners are costumed in orange prison jumpsuits, with manacled ankles and wrists. This powerful stage picture immediately categorizes the prisoners as dehumanized and undifferentiated, humiliated and without agency. But the language of the play, taken from transcribed, real sources, reinvests the prisoners with strongly individual characterizations, mainly through the pathos of the stories of their capture and transfer to the prison, and the sympathy elicited through their remembrances of their family lives and the normal existence from which they have been snatched away. As in Black Watch, a situation that feels distant, alien and disturbing is energized, personalized and enriched with detail and context, so that it feels both engaging on a personal level and also publicly relevant.

\section{New times}

I began by defining a theatrical context in Britain, which has seen a burgeoning of fact-based plays and performances in the 1990s and 2000s. The 'Acting with Facts' project began from the premise that fact-based drama has become both more visible in British culture since about 1990 and that there is simply more of this kind of work in the public domain than hitherto. In this article, as a way of setting up the significance of fact-based theatre in the British theatre context specifically, I have highlighted some of the forces and debates that have underpinned the higher profile of fact-based theatre since the 1990s and reflected upon the theatrical and political contexts that have given rise to an escalation of 
interest in these forms of drama. Of course, documentary theatre did not begin in the 1990s. Documentary theatre has a long history, notably in the vigorous British and European theatre traditions of the twentieth century that were premised on engagement with the contemporary moment and saw themselves as connected with progressive movements for social betterment. But I would ague that in the late 1990s a renaissance in documentary theatre arose out of a vacuum in political discourse and a perceived reluctance publically to interrogate established institutional systems. A crisis in British theatre in the 1980s was propelled by both economics and ideology, and swept away much of the foregoing activity with bewildering effectiveness. Documentary theatre along with In-Yer-Face theatre came to dominate contemporary British theatre because each bears witness to 'new times' and new needs.

This is not to say that documentary theatre, and indeed In-Yer-Face theatre, is not problematic and Carol Martin has characterized documentary theatre as 'inventing its own particular truth through elaborate aesthetic devices'. She goes on to ask: 'Is documentary theatre just another form of propaganda, its own system of constructed half-truths for the sake of specific arguments?' (Martin 2006: 10). Fact-based theatre claims to focus on the presentation of the reality of an event or series of events by claiming faithfulness or closeness to the documentary material. Black Watch and Guantanamo both assert a kind of authenticity through their engagement with personal stories, though in very different ways since the former is very energetic and vigorous while the latter is very still and restrained. In both performances the material is offered in order to connect to the audience sensibilities through visceral engagement, in Black Watch through expressive physicality and in Guantanamo through confinement and 
bodily restriction. They share the topic of people caught in war who are powerless and yet become subject to and physically affected by it. Both plays are examples of the ways fact-based drama uses revelation and veracity to create Megson's 'poetics of immediacy'. It offers 'directness' in its claimed association with real people and real events in a world dominated by mediation, hyper-reality and imitation.

But Martin's comment and questions hint at the suspicions that surround documentary theatre. Stephen Bottoms in his article 'Putting the Document in Documentary: An Unwelcome Corrective' encapsulates the critique of British documentary theatre's claim to present a 'direct' unmediated truth (Bottoms 2006: 56). For him the lack of self-referentiality and reflexivity in most documentary theatre brings the plays too close to transparent reconstruction, without acknowledging their manipulative potential. For Bottoms, rhetoric (and performance) that 'obscures the fact that realism and reality are not the same thing, and that unmediated access to "the real" is not something the theatre can ever honestly provide', is misleading, even deceitful (Bottoms 2006: 57). He goes on to say:

theatrical self-referentiality $[\ldots]$ is precisely what is required of documentary plays if they are to acknowledge their dual and thus ambiguous status as both 'document' and 'play.' Without a self-conscious emphasis on the vicissitudes of textuality and discourse, such plays can too easily become disingenuous exercises in the presentation of 'truth,' failing (or refusing?) to acknowledge their own highly selective manipulation of opinion and rhetoric.

(Bottoms 2006: 57) 
This raises the question of whether what I identify as 'enlistment' can offer a positive means of audience engagement that has the potential to harness social and political agency, or whether, in its aspirations to elicit emotion and achieve immediacy and directness, it is merely exploitative manipulation.

I have described emotional enlistment as a potential because I regard it as a quantity of affect produced in the relationship between the audience and the performance. As a quantitative phenomenon, the emotion enlisted does not lead in a particular cognitive direction. It does not have, in itself, a political orientation. Rather the play in performance can offer the means to channel the predisposition energized by enlistment into a route for political expression. The play builds up an emotional engagement but must also transfer it into assent for a political idea. There could be reactionary and complicit ways of deploying this energy as well as progressive ones. But in the context of contemporary distrust of grand narratives, fact-based dramas about the failures and corruption of institutions can generate emotional enlistment and channel it towards a demand for the reform of institutions and the public sphere. This may not be the politics of revolution but it is the politics of reform, which might be as much as we can ask for at present.

Both Black Watch and Guantanamo are tricky examples. Neither conforms entirely to the unreflexive model that Bottoms critiques since the former foregrounds its construction as a fact-based performance through the presence of the writer and the self-conscious use of news media, and the latter gives some emphasis to the self-conscious use of documentary material in the form of letters or legal documents and the play is structured with a very specific critical frame. At the same time, both the plays deploy strategies specifically to raise the 
emotional stakes, which might be termed manipulative - just a couple of examples being the use of the bagpipes in Black Watch and continual references to family in Guantanamo. Certainly Black Watch could be open to accusations of sentimentality in its representation and idealization of the Black Watch Regiment as heroes/anti-heroes, made all the more poignant by its pending disbandment and amalgamation into The Royal Regiment of Scotland (in 2004 when the research took place). In its performance style, through the use of language and music it evokes a feeling of Scottish autonomy to which the audience responds emotionally. But the vivid explanation of the Black Watch's history as a 'golden thread' that 'connects the past, present and future of the regiment', for example, sidesteps problems of politics and identity raised by the regiment's service in Northern Ireland during the Troubles (Burke 2007: 25). Guantanamo's focus is entirely on prisoners who claim to be innocent of taking part in the wars in Afghanistan or Iraq. Similarly, Tom Clark, the young man depicted whose sister was killed in the 9/11 atrocity, shows little animosity towards the terrorists responsible, rather he explains his sister's genuine concern with injustice in the Middle East. She (and he) too is an innocent victim of western imperialism. There is no attempt to grapple with what might be a far more challenging issue, the injustice of the imprisonment without the protection of the Geneva Convention of a captive who might indeed be fighting for the Afghans or the Iraqis. ${ }^{12}$ In asserting the innocence of the captives, the play can sidestep some of the issues around the illegalities of the prison itself and more importantly it can build up an unproblematic emotional relationship between the audience and the characters.

Recent documentary theatre concerns public, political issues where a deficit in democratic debate has been identified and it uses observation and the 
cultivation of sympathy to enlist its audience in a shared understanding of what is hidden, not understood or not noticed. It may not offer the comfort or enthusiasm of rallying the audience to a cause, but it makes acquiescence shameful.

I have not argued that In-Yer-Face theatre and fact-based theatre are the same in their affective dynamics. There are clear differences between these forms, but both were avowedly keen on not telling the audience what to think, and such a criticism was often levelled at the versions of Brecht that had informed the practices of the former self-consciously political drama. Both lay claim to a kind of realism that confronts actuality, be that of situation or experience, through forms of theatre that cultivate emotional engagement as a way of puncturing the insensitive complacency or exhaustion of a pre-1989 generation. For each form this is a realism of affective relationship, with a repellent and disturbing environment or with a set of actual events and the audiences' participation in an experience perceived to be urgent and affecting. Documentary theatre stirs up indignation, public protest and sympathy, despite its 'self-imposed austerity on stage' as Paola Botham would have it (Botham 2008: 315). It aims to engage the audience emotionally in order to achieve its objective in a contemporary world where the emotional is cultivated as a primary means of marshalling and impelling action in the current political climate, and where the phenomenological has become a significant strand of critical discourse about theatre. Where documentary theatre differs from In-Yer-Face theatre is in its attitude to society and its governing principles. Despite its critique of established institutions, it nevertheless endorses their social and political role rather than aiming at new brutalist theatre's detonation of established authorities. In-Yer-Face theatre envisions an unmitigated nihilistic bleakness, where there is no expectation of 
remedy for the situation portrayed and no assumption that the institutions of society are relevant to the worlds that are represented. By contrast, fact-based plays address a specific issue, moment or group of people, and their contexts, within a didactic, analytical form that attempts to persuade and reason with its audience. This expectation of rational debate, desire for public and often institutional solutions, and engagement with the audience as a concerned interlocutor hollow out a space for the audience to be engaged in a Habermasian dialogue about public affairs. ${ }^{13}$ While Kane and Ravenhill incite a response based on hostility and disaffection, and work to inflame emotions, Norton-Taylor, Gupta and Burke provoke a response that also harnesses emotion but to enlist the audience's reason and sympathy, to bring them on-side rather than to alienate and confront them.

\section{References}

Botham, Paola (2008), 'From deconstruction to reconstruction: A Habermasian framework for contemporary political theatre', Contemporary Theatre Review, 18: 3, pp. 307-17.

Bottoms, Stephen (2006), 'Putting the document into documentary: A unwelcome corrective', TDR: The Drama Review, 50: 3, pp. 56-68

Brenton, Howard and Hare, David (1985), Pravda: A Fleet Street Comedy, London: Methuen.

Brittain, Victoria and Slovo, Gillian (2004), Guantanamo, London: Oberon Books. 
Burke, Gregory (2007), Black Watch, London: Faber.

Cheeseman, Peter (1970), The Knotty: A Musical Documentary, London:

Methuen.

D’Monté, Rebecca and Saunders, Graham (eds) (2007), Cool Britannia: British Political Drama in the 1990s, Basingstoke: Palgrave Macmillan.

Donne, John (1987), 'Meditation XVII', Devotions Upon Emergent Occasions

(ed. with commentary, by Anthony Raspa), Oxford: Oxford University Press, pp. 86.

Edgar, David (1976), Destiny, London: Methuen.

Gupta, Tanika (2005), Gladiator Games, London: Oberon Books.

Hammond, Will and Steward, Dan (eds) (2008), 'David Hare and Max Stafford-

Clark', in Verbatim Verbatim, London: Oberon, pp. 45-75.

Hare, David (1990), Racing Demon, London: Faber.

(1991), Murmuring Judges, London: Faber.

(1993), Absence of War, London: Faber

(2003), The Permanent Way, London: Faber.

(2004), Stuff Happens, London: Faber.

(2009), The Power of Yes, London: Faber.

Kane, Sarah (2001), Sarah Kane: Complete Plays, introduced by David Greig, London: Methuen. 
Kershaw, Baz (1990), The Politics of Performance: Radical Theatre as Cultural Intervention, London: Routledge.

Martin, Carol (2006), 'Bodies of evidence', TDR: The Drama Review, 50: 3, pp. $8-15$.

Megson, Chris (2006), 'Backpages', Contemporary Theatre Review, 16: 4, pp. $529-32$.

Neilson, Anthony (1998), Anthony Neilson: Plays One, London: Methuen.

Norton-Taylor, Richard (ed.) (1999), The Colour of Justice: Based on the Transcripts of the Stephen Lawrence Inquiry, London: Oberon Books. (2005), Bloody Sunday: Scenes from the Saville Inquiry, London: Oberon Books.

(2003), Justifying War: Scenes from the Hutton Inquiry, London: Oberon Books.

Paget, Derek (1987), “ "Verbatim Theatre”: Oral history and documentary techniques', New Theatre Quarterly, 3: 12, pp. 317-36.

Ravenhill, Mark (2001), Plays, introduced by Dan Rebellato, London: Methuen.

Reinelt, Janelle (2009), 'The promise of documentary', in A. Forsyth and C.

Megson (eds), Get Real, Basingstoke: Palgrave Macmillan, pp. 6-23.

Sierz, Aleks (2001), In-Yer-Face Theatre: British Drama Today, London: Faber.

Soans, Robin (2005), Talking to Terrorists, London, Oberon Books. 
Sobchack, Vivian (1992), The Address of the Eye: A Phenomenology of Film

Experience, Princeton, NJ: Princeton University Press.

US Code; Title 10, Act of 5 May 1960 replacing the wording first adopted in 1789, with amendment effective 5 October 1962.

Weiss, Peter. (1971), 'The material and the models: Notes towards a definition of documentary theatre' (trans. Heinz Bernard), Theatre Quarterly, I: 1, pp. 41-43.

Young, Stuart (2009), 'Playing with Documentary Theatre: Aalst and Taking

Care of Baby', New Theatre Quarterly, 25: 1, pp. 72-87.

Sierz, Aleks, In-Yer-Face Theatre, http://www.inyerface-theatre.com/what.html. Accessed 30 April 2009.

\section{Suggested citation}

Taylor, L. (2011), 'The experience of immediacy: Emotion and enlistment in fact-based theatre', Studies in Theatre and Performance, 31: 2, pp. 223-237, doi: 10.1386/stp.31.2.223_1.

\section{Contributor details}

Lib Taylor is Professor of Theatre and Performance in the Department of Film, Theatre \& Television at the University of Reading. She has published on the body in performance, women's theatre and contemporary British theatre. She is a director and devisor of theatre research performances that have recently included performances of Marguerite Duras's later plays and a piece based on the theatre 
writings of Gertrude Stein. She was a co-investigator on the AHRC-funded

Acting with Facts project.

E-mail: 1.j.taylor@reading.ac.uk

Notes

${ }^{1}$ Megson's article reports on Central School of Speech and Drama's symposium Verbatim Practices in Contemporary Theatre (London, July 2006).

${ }^{2}$ See Shellard, D. (1999), British Theatre Since the War, New Haven: Yale University Press, pp. 187-229.

${ }^{3}$ Examples would be David Hare's Plenty (1978), an analysis of contemporary 1970s Britain through a historical lens, from 1944 to 1962 and David Edgar's Destiny (1976), which examined post-World War II British Fascism.

${ }^{4}$ See Saunders (2007), 'Introduction'.

${ }^{5}$ The Royal Court is an example of a theatre that encourages new writing and that produced many of the new plays in the 1990s that might be called In-Yer-Face theatre (plays by, for example, Sarah Kane, Mark Ravenhill, Anthony Neilson and Philip Ridley).

${ }^{6}$ See Kershaw (1990), 'Part 1', pp. 13-92 for discussion of the significance of agitprop for community theatres of the 1960s and 1970s.

${ }^{7}$ See John Abberley's, 'We all have private thoughts that aren't voiced to others', The Sentinel, 30 April 2010.

${ }^{8}$ See Paget (1987) for discussion of the working models and methods of 1970s and 1980 s documentary theatre.

${ }^{9}$ The 'Federal Theatre Project' (1935-39) was a New Deal initiative established to fund theatre in the United States as a way of creating employment for actors, writers, artists and directors during the Depression. The Living Newspaper was one arm of the poject, which developed popular theatre based on factual information and current social issues. Joint Stock Theatre Company (1974-89) was set up by David Hare, Max Stafford-Clark and David Aukin in 1974. It developed a particular approach to the creation of new theatre writing whereby the writer worked in collaboration with the company in order to research material for plays often based on fact. Hare has used some Joint Stock ways of working in recent plays, including The Permanent Way (2003 - directed by Stafford-Clark), Stuff Happens (2004) and The Power of Yes (2009).

${ }^{10}$ The Colour of Justice is based on the public inquiry into the police investigation of the murder of black teenager Stephen Lawrence, stabbed to death in 1993.

Gladiator Games focused on the ineptitude of the British judicial system 
following the death of the young British Asian man, Zahid Mubarek, from injuries he received at Feltham Young Offenders Institution, London.

${ }^{11}$ Justifying War presents a dramatization of the Hutton Inquiry's investigation of the suicide of Dr David Kelly following assertions that he was the source of claims about the dossier on weapons of mass destruction. Bloody Sunday: Scenes from the Saville Inquiry reconstructs scenes from the Saville Inquiry's investigation into the events of Bloody Sunday in Londonderry, Northern Ireland, in 1972.

${ }^{12}$ The US Government asserted that the Guantanamo detainees were not entitled to protection under the Geneva Convention until 2006, when the US Supreme Court ruled that the detainees were entitled to minimum protection. This ruling was after the first performance of the play.

${ }^{13}$ See Botham (2008) for the significance of Habermas's notion of the 'public sphere' for documentary theatre. 